\title{
Substrate as insect feed for bio-mass production
}

\author{
L. Pinotti" (iD) and M. Ottoboni iD \\ Department of Health, Animal Science and Food Safety 'Carlo Cantoni', University of Milan, via dell'Università 6, 26900 \\ Lodi, Italy; luciano.pinotti@unimi.it
}

Received: 31 August 2020 / Accepted: 3 February 2021

(c) 2021 Wageningen Academic Publishers

OPEN ACCESS C(1) R(? REVIEW ARTICLE

\begin{abstract}
Insects are able to convert organic material (i.e. waste and by products) into high-quality biomass, which can be processed into animal feed. Several studies have investigated the influence of growing substrates on the nutritional value of different insect species, particularly black soldier fly larvae and prepupae. This article reviews studies on how insects bioconvert different substrates, the effect of the substrate on the composition of insect meals, and on the development time (time needed to reach the harvesting state). All these studies indicate that insects convert low and high quality organic material (i.e. waste, by products, compound feeds) into high-quality insect biomass. The role and effects of selected nutrients, such as ether extract/fats, carbohydrates and fibre in the substrate, seem to be key factors in defining the features of the biomass as well as the time needed to reach the harvesting state.
\end{abstract}

Keywords: substrates, black soldier fly, circular economy, innovative feed ingredients

\section{Introduction}

One of the most important requirements for any animalproducing farm is the biomass that the farmer uses for feed. As insect farming is a relatively new and currently small but fast growing enterprise, there is little knowledge regarding the optimal nutritional content each farmed species needs for maximal productivity.

The concept of 'feed' in terms of insects is not very well defined. There are more than 900 different agricultural products that are used to produce/prepare animal feed (FAO, 2013), and usually the traditional feed classification includes the following categories: (1) roughage; (2) concentrate; (3) feed supplements; and (4) feed additives.

There are no such feed categories for farmed insects. The reason for this is related to the insect's ability to upgrade low nutrient substrates such as industrial co-by-products and vegetable waste (Dicke, 2018; Pinotti et al., 2019). In fact, a wide range of organic materials can be used as a source of nutrients or as substrates for insect rearing. These depend on the availability, the legislative framework, applicability in the specific farming system, and the cost.
According to the definition of 'farmed animals' (EC, 2009b), insects bred for the production of processed animal proteins (PAPs) are considered as farmed animals, and are therefore subject to 'feed ban' rules (EC, 2001) as well as the rules of animal feeding (EC, 2009b). Thus, PAPs and insects are closely connected (EC, 2017; Ottoboni et al., 2017), although in opposite ways.

This review covers the main different rearing substrates reported in the literature for farmed insects and provides a broad analysis of the different substrates used for all insects, with a specific focus on those used for black soldier fly (BSF) larvae.

\section{Type of substrates}

'Substrate' is the overall term applied for the materials used as insect feed. The use of substrates for the growth of insects is still an open issue. Currently there are two categories, those that are legally permitted and those that are not. The line between these two categories differs depending on the different authorities and countries.

In the EU, for instance, the use of several substrates such as ruminant proteins, catering waste, meat-and-bone 
meal and manure is prohibited (EC, 2009a), in line with regulations on transmissible spongiform encephalopathies and bovine spongiform encephalopathy. Furthermore, certain substrates, such as manure and intestinal contents, catering waste or former foodstuffs containing meat and fish, as well as human manure and sewage sludge, are also not allowed. Specifically, in its risk assessment (EFSA, 2015), the European Food Safety Authority (EFSA) considers the following seven categories (from A to G) of substrates:

A. Animal feed materials according to the EU catalogue of feed materials (Commission Regulation (EU) No $68 / 2013$ ) and authorised as feed for food producing animals (EC, 2013).

B. Food produced for human consumption, but which is no longer intended for human consumption for reasons such as expired use-by date or due to problems of manufacturing or packaging defects. Meat and fish may be included in this category.

C. By-products from slaughterhouses (hides, hair, feathers, bones, etc.) that do not enter the food chain but originate from animals fit for human consumption.

D. Food waste from food for human consumption of both animal and non-animal origin from restaurants, catering, and households.

E. Animal manure and intestinal content.

F. Other types of organic waste of vegetable nature such as gardening and forest material.

G. Human manure and sewage sludge.

In Western countries the main substrates currently used for insect production thus include commercial animal feed, co-products from the primary production of nonanimal origin food, and former foodstuffs (not containing meat and fish) for example production surplus, misshapen products, food with expired best-before-dates that have been produced in compliance with food legislation which have been already proposed as valid carbohydrates/energy sources in animal nutrition (Giromini et al., 2017; Luciano et al., 2020; Ottoboni et al., 2019; Pinotti et al., 2019, 2020, 2021; Tretola et al., 2019). By contrast, in other countries (e.g. African countries), a wide range of bio-waste products are readily available and used as substrates for insect rearing, and these organic materials, for example animal manure, are typically composted or heat-treated before use (Münke-Svendsen et al., 2017).

Other feed substrates commonly used by farmers include conventionally compounded meals made from seasonally available cereals and legumes such as maize, sorghum and soybeans, and indigenous vegetables such as collard greens, jute mallow, amaranth leaves, black nightshade, cowpea leaves, and spider plants.
Insect producers also use local substrates, such as forage leaves, as a substitute for vegetables during the dry season (Münke-Svendsen et al., 2017). These include cassava, banana, sweet potato, tomato, pawpaw, and moringa leaves. These feed items are highly sought after by other farming activities as well, and are also used as food for humans (Münke-Svendsen et al., 2017).

Insect producers select substrates based on a number of criteria, including the nutritional composition, expected effects on the insect species such as weight gain (also known as biomass production), feed efficiency (feed conversion ratio), finally the time needed to reach the harvesting stage, and steady year-round supply. In terms of the quality of the derived insect biomass, the key issues are protein concentration and amino acid profile, the fatty acid profile, micronutrients (such as minerals), the absence of hazards, or ease of removal during harvesting.

A further key issue in terms of efficiency and quality is the water content. A recent study (Dzepe et al., 2020) in which five substrates moisture content levels $(40,50,60$, 70 and $80 \%$ ) were tested, indicated that increasing the substrate moisture content reduces the larval feed reduction (mass reduction, \%; Salomone et al., 2017), wet weight, development time, and body size and body thickness of the larvae. This is in line with another study (Lalander et al., 2020), which reported that adding too much water content reduced the biomass conversion ratio and survival rate of the larvae. In fact, substrates with a water content of between $80-90 \%$, can only be used in combination with ventilation, while very wet substrates with a water content of over $90 \%$ were not considered suitable for BSF larvae compost even with active ventilation. These findings could have implications for the waste management sector interested in the fly larvae treatment of fruit and vegetable wastes. This is because the BSF larvae composting of wet substrates is simpler if a dry separation of the larvae from residue is carried out after the completed treatment, thus rendering this option viable for a wider range of substrates (Lalander et al., 2020). Efficient drying is one of the key elements in producing a profitable feed. Typically, dryers will use between $3,000 \mathrm{~kJ} / \mathrm{kg}$ and $4,500 \mathrm{~kJ} / \mathrm{kg}$ of evaporated water (Hamm, 2017). However, complete water removal is not required in insect rearing for substrate preparation, indeed certain species of insect, such as BSF, can be reared on substrates containing up to $80 \%$ moisture (Lalander et al., 2020). This opens up new scenarios in insect substrate evaluation, since wastewater residues from the starch industry and cheese industry, for instance, can be considered as wet nutrient sources to rear insects, with benefits in terms of cost and performance. Accordingly, by adopting these strategies (incomplete or no drying for insect substrates), drying costs can be reduced or avoided. 


\section{Potential of insects in upgrading waste material and organic streams}

Irrespectively of the legal basis, several substrates can be used in insect farming, namely: chicken feed, manure/ faeces/sludge/abattoir waste, industrial by-products, fruit and vegetables, vegetable and cereal-based standard insect diets, restaurant and food waste, animal based products and by-products, straw, and algae. This is also in line with the 14 studies listed in Table S1, in which more than 50 different types of substrates have been tested on the same insect species (i.e. BSF larvae). Eight classes/categories were identified, namely chicken feed, manure digestate sludge, industrial by-products, fruit and vegetables, standard diet BSF, animal by-products, straw, and algae.

Figure 1 reports the mean, quartiles, minimum and maximum observations and outliers for normalised BSF biomass yield (g dry matter (DM) biomass yield from 100 young larvae) from the different substrate categories. From these records, even if case sensitive, it is clear that the best performing substrates are those characterised by 'balanced diets' in terms of nutrients composition and profile. This is the case of chicken feed and BSF standard diets proposed in different studies. Poultry diets, for instance, are composed primarily of a mixture of several feedstuffs such as cereal grains, soybean meal, fats, and vitamin and mineral premixes. These diets provide the essential energy and nutrients that are essential for fowl growth, reproduction, and health, namely proteins and amino acids, carbohydrates, fats, minerals, and vitamins. The energy necessary for maintaining the chicken's general metabolism and for producing meat and eggs is provided by the energyyielding dietary components, primarily carbohydrates and fats, but also protein. Similarly, in insects, the best growing performance are obtained when a complete/balanced feeding media (i.e. chicken feed) is used. Indeed, such substrate in general are rich in energy and protein, while balanced for all nutrients (Barragán-Fonseca et al., 2018). By contrast, straw and algae substrates did not guaranteeing adequate insect biomass yields, probably due the presence of different anti-nutritional factors (ANFs). Straw is a crop residue consisting of the dry stems and leaves left over after the harvest of cereals, and legumes (Heuzé, and Tran, 2015). In term of nutrient content, straw is considered a lignocellulosic biomass, indeed it contain cellulose (38\%), hemicelluloses (25\%), lignin (12\%) (Gummert et al., 2020). As feed for farm animals, all types of straw consist of coarse, high-fibre, low-protein and low-digestibility roughage (Gummert et al., 2020). For insect however the situation is more controversial: the high quantity of rice straw in the substrate (daily feeding of $200 \mathrm{mg}$ of ground rice straw per larvae) resulted in the highest prepupal dry weight, lowest (i.e. quick) developmental time, but lowest waste reduction efficiency $(10.85 \%)$. The highest waste reduction efficiency (31.53\%) was recorded by larvae fed at the lowest straw rate (12.5 mg of straw/larvae/day) (Manurung et al., 2016). Another recent study (Liu et al., 2018) reported that among the different types of fibre (acid detergent fibre; ADF, neutral detergent fibre; NDF, hemicellulose, cellulose, lignin) all of them, with the exception of hemicellulose, had negative effect on larval growth. Among ADF, NDF, cellulose, and lignin however, lignin has shown the strongest negative impact. This is in also explained by the fact that very often, in vegetable matrix, hemicellulose and cellulose are linked to lignin, which in turn protects them from digestion (Liu et al., 2018). However, the ability of BSF larvae to bio convert fibre rich substrate may be partially explained by the presence, in the digestive tract of the insect, of intestinal bacteria able to degrade cellulose (Kim et al., 2014b). Thus, based on these findings it seems that insects have some potential in digesting some fibre fraction (i.e. cellulose and hemicellulose), even though other factors might be important in defining larvae growth performance (e.g. larvae density; Barragán-Fonseca et al., 2018).

The same low growth rate has been reported when algae are used as substrate: by increasing the inclusion of brown algae in the feeding medium, the BSF larvae had a reduced growth and feed intake. The reason for this is unknown although recent publications have reported the presence of several ANFs in algae in general, and Ascophyllum nodosum in particular. These marine materials contain alginate and fucoidan, which have several side effects. Alginate extract is used in reducing the appetite and energy intake in humans (Hall et al., 2012), whereas Fucoidan is an efficient inhibitor of $\alpha$-amylase and $\alpha$-glucosidase (Kim et al., 2014a). Both these ANFs, probably affect the feed efficiency of seaweed as a feeding media for insects, although their percentage in the diet is important in defining such negative effects. The reduced insect growth rate however is in contrast with the nutrient profile of seaweed which can also contain several micronutrients. Algae contain iodine, sterols, essential amino acids/fatty acids (e.g. eicosapentaenoic acid) and vitamin E (Liland et al., 2017). Thus, insect larvae can act as carriers of such essential nutrients from sources not directly suitable for human or animal nutrition, in human or animal diets. This ability can be used to tailor the composition of the insect larvae towards the desired nutrient profiles to be used as livestock-feed ingredients (Liland et al., 2017; Pinotti et al., 2019).

Combining the findings of different studies (Supplementary Table S1) however, the potential of insects to upgrade waste material and organic streams is clear. This is confirmed when considering the three major nutrient groups including proteins, lipids, and carbohydrates (P, L, and C) (Ortiz et al., 2016). To calculate PLC ratios, each major nutrient (P, L, and $C$ ) percentage is divided by the sum of the percentages of proteins, lipids, and digestible carbohydrates (total carbohydrate; fibre). The sum of the three ratios (P, L, and C) should always be 1 . 


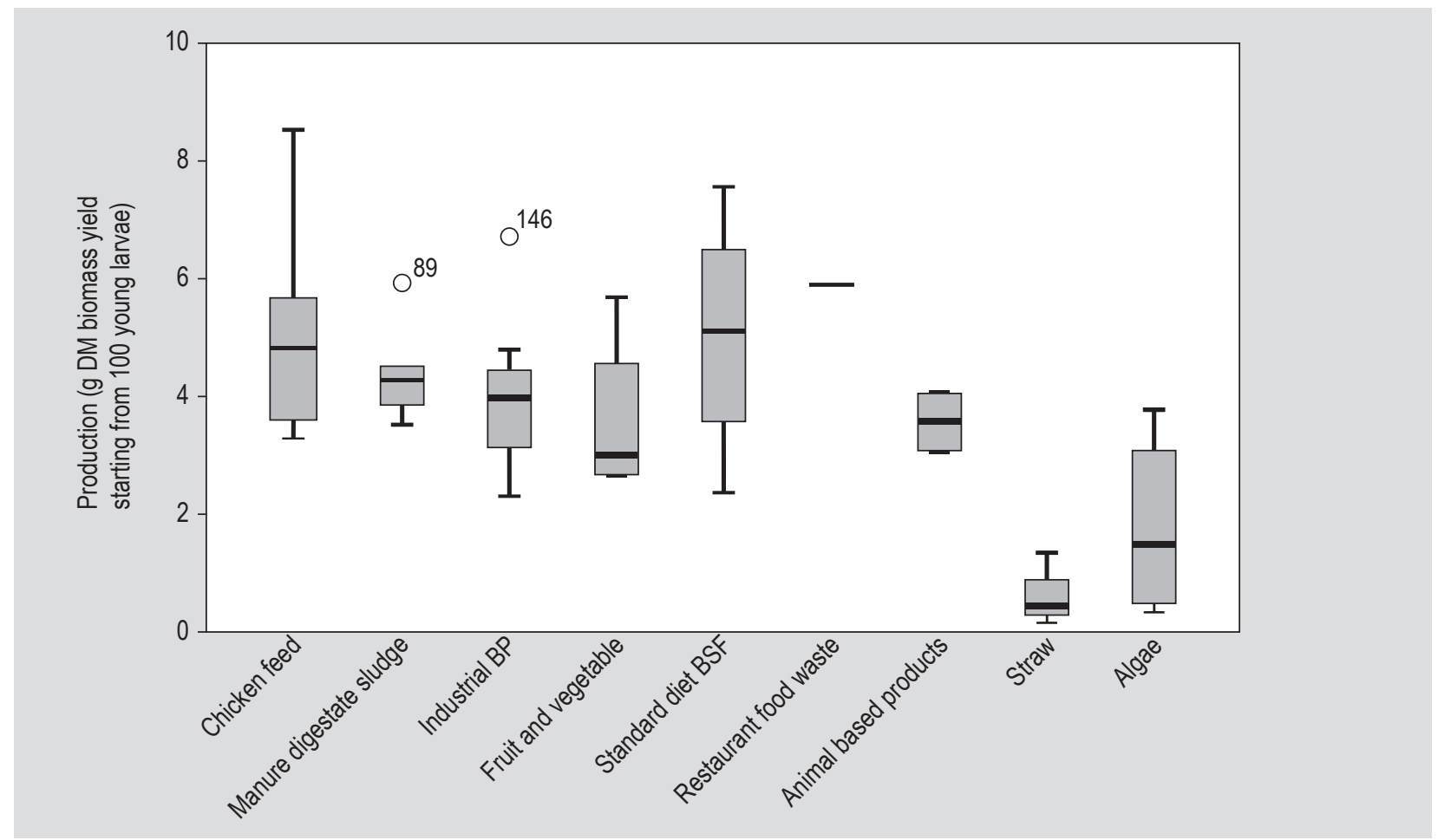

Figure 1. Mean, median, quartiles, minimum and maximum observations and outliers for larval biomass yield production (grams of larval biomass yield on the basis of 100 young larvae). $D M=$ dry matter.

The contents of the major nutrient groups and PLC ratios of the food ingredients commonly used in diets for farmed insects are presented in Figure 2 and 3. The two figures show how insects are able to upgrade and convert unbalanced carbohydrates based (70-90\%) substrate into a more balanced biomass combining carbohydrates, proteins and lipids. This is in line with data reported by Spranghers et al. (2017), who reported that BSF larvae synthesise fatty acids, above all lauric acid (C12:0), using non-fibre carbohydrates contained in the substrate. This feature seems to be specific for this insect species, in fact when comparing the fatty acid profile of the prepupae with that of their respective substrates, it appears that the substrate has a limited effect on the fatty acid profile of the prepupae. Interestingly, in the same study, lipids of the harvested prepupae were mainly composed of C12:0, even when the substrate only contained this fatty acid in trace amounts.

\section{Insect vs substrates}

In order to facilitate a comparison, two representative studies were selected, namely Spranghers et al. (2017) and Meneguz et al. (2018), in which eight different substrates were tested (Table 1; Figure 4).

Combining substrate features with insect (BSFL) biomass led to various conclusions. The crude protein content, and the chitin corrected crude protein content in larval biomass both varied (mean 307-530 and 234-403 g/kg DM, respectively) among different types of substrate used for growing larvae. These figures are based on two assumptions: (1) all the nitrogen in the food is present as protein; (2) all food protein contains $160 \mathrm{~g} \mathrm{~N} / \mathrm{kg}$ (McDonald et al., 2012). Accordingly, the nitrogen-to-protein conversion factor, is set at 6.25; and second chitin is excluded when calculating the protein content, which implies the use of the nitrogento-protein conversion factor, of 4.76. In fact, the presence of non-protein nitrogen (NPN) in insects, i.e. chitin, may lead to an overestimation of the protein content. A nitrogento-protein conversion factor (Kp) specific for insect larvae $(\mathrm{Kp}=4.76)$ has been proposed (Janssen et al., 2017). This Kp value is calculated from the ratio of the sum of the amino acid residue weights to nitrogen content. This enables the 'real protein content' to be estimated, which is $24 \%$ lower than the protein content based on a Kp of 6.25. These values however, were obtained using a low protein substrate (mean $14 \%$ crude protein (CP) on DM basis).

However, considering a protein upgrade of the substrate for both values (crude protein and the chitin corrected crude protein contents), an increase of between 2.1 and 2.8 was recorded. In fact, in both studies, the larval biomass protein content was at least twice the protein content recorded in the substrate. These upgrade figures were 5.2 in the case of fats. Rearing substrates were generally characterised by a lower lipid input compared to larval biomass ( 86 and $287 \mathrm{~g} / \mathrm{kg}$ DM, respectively). There was a small variability in the lipid content in the rearing substrates, whereas by 


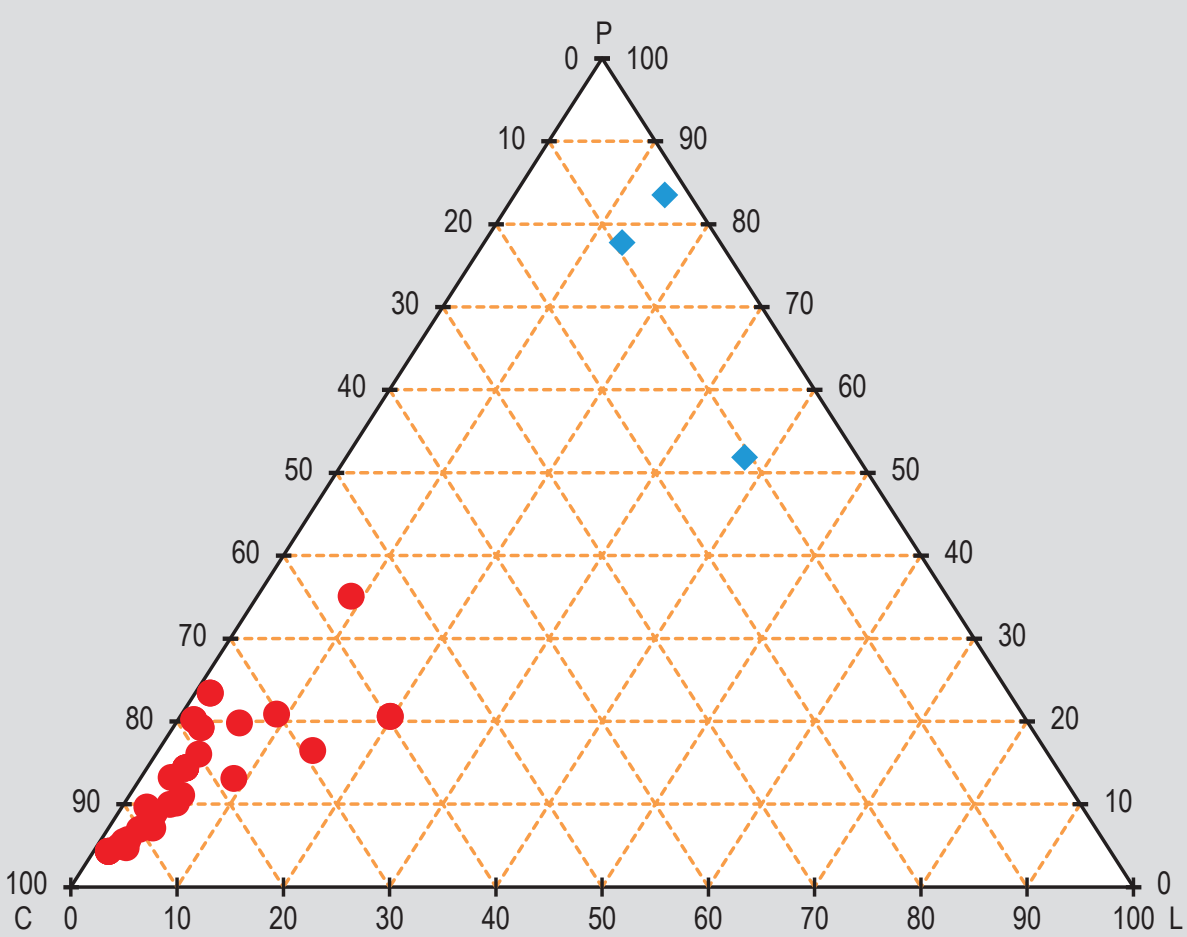

Figure 2. Ternary plot of protein, lipid, and carbohydrate (PLC) ratios of substrate used for rearing black soldier flies. Carbohydrates are determined by the following calculation on dry matter basis: carbohydrates $=100-(\%$ crude Ash $)-(\%$ crude fat $)-(\%$ crude protein). Substrate are classified as: vegetable substrate, circles (•); and animal based products, diamonds ( $\diamond)$. Data elaborated from Biancarosa et al. (2017); Bruno et al. (2019); Liland et al. (2017); Ma et al. (2018); Manurung et al. (2016); Meneguz et al. (2018); Nguyen et al. (2013, 2015); and Spranghers et al. (2017).

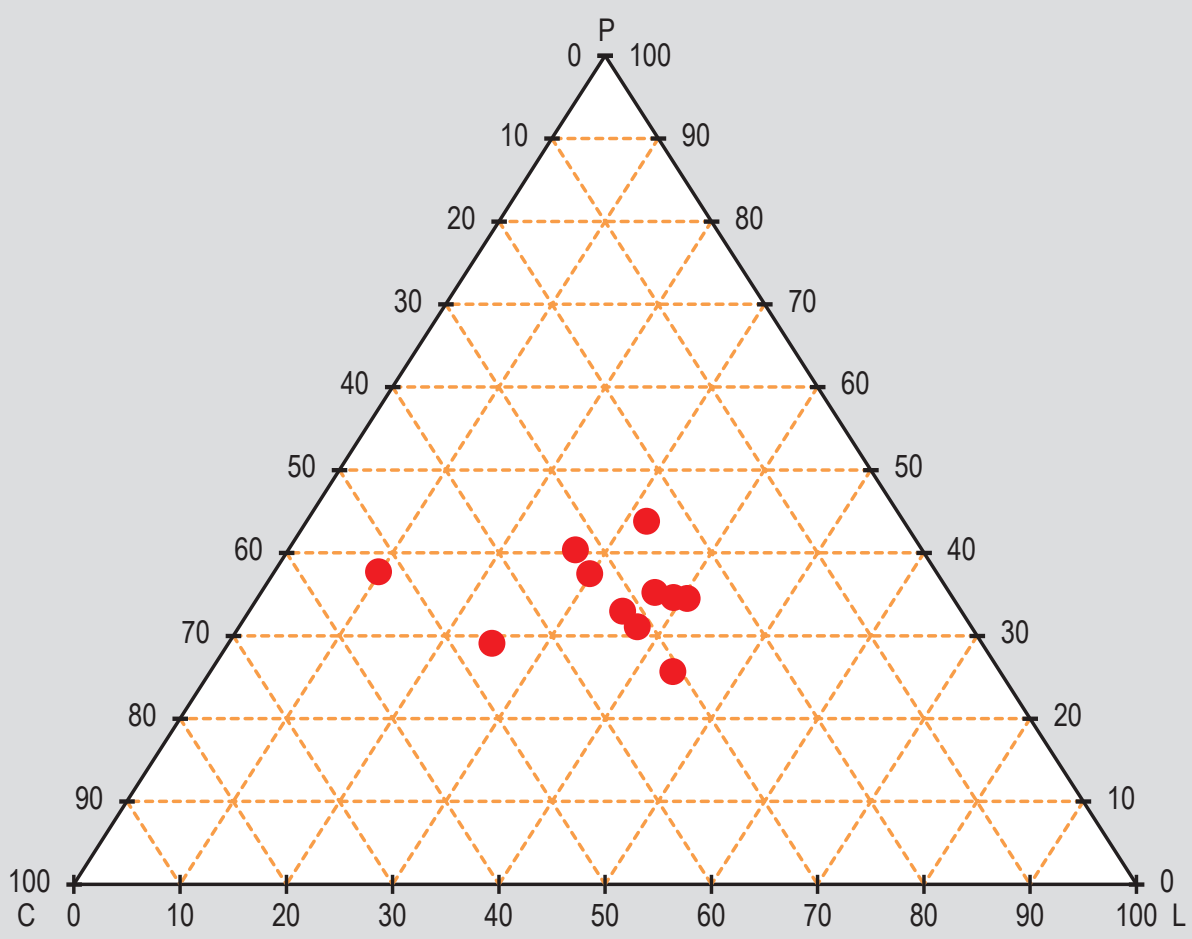

Figure 3. Ternary plot of protein, lipid, and carbohydrate (PLC) ratios of BSF prepupae biomass. Carbohydrates are determined by the following calculation on dry matter basis: carbohydrates $=100-(\%$ crude ash $)-(\%$ crude fat $)-(\%$ crude protein $)$. Data elaborated from Biancarosa et al. (2017); Liland et al. (2017); Meneguz et al. (2018); and Spranghers et al. (2017). 
Table 1. Selected studies on black soldier fly (BSF) considered in this review and the main inputs considered. ${ }^{1,2}$

\begin{tabular}{|c|c|c|c|c|c|c|c|c|c|c|c|c|c|c|c|}
\hline \multirow[t]{3}{*}{ Study } & \multicolumn{8}{|l|}{ Substrates } & \multicolumn{7}{|c|}{ Insect larvae (BSF) } \\
\hline & & w & $\mathrm{CP}$ & $\mathrm{EE}$ & ash & $\begin{array}{l}\text { IDF/ } \\
\text { NDF }^{*}\end{array}$ & $\mathrm{NFC}^{*}$ & Energy* & $\begin{array}{l}\text { Development } \\
\text { time (day) }\end{array}$ & $\begin{array}{l}\text { Production } \\
\text { g DM }\end{array}$ & $\begin{array}{l}\mathrm{CP}^{*} \\
(\mathrm{kp} 4.76)\end{array}$ & $\begin{array}{l}C P^{*} \\
(k p 6.25)\end{array}$ & $\mathrm{EE}$ & Ash & Energy* \\
\hline & & $\mathrm{g} / \mathrm{kg}$ & \multicolumn{4}{|c|}{ g/kg DM } & \multicolumn{3}{|c|}{ kcal/kg DM } & & \multicolumn{2}{|l|}{ g/kg DM } & & & $\mathrm{kcal} / \mathrm{kg} \mathrm{DM}$ \\
\hline Meneguz et & Brewery by-products & 917 & 200 & 86 & 40 & 447 & 225 & 2,910 & 8 & 2.29 & 403 & 530 & 299 & 73 & 5,107 \\
\hline \multirow[t]{3}{*}{ al., 2018} & Winery by-products & 868 & 117 & 79 & 103 & 566 & 134 & 1,724 & 22.2 & 3.09 & 262 & 344 & 322 & 146 & 3,950 \\
\hline & Fruit waste & 641 & 46 & 28 & 30 & 139 & 756 & 3,590 & 22 & 2.63 & 234 & 307 & 407 & 72 & 4,825 \\
\hline & Fruit and vegetable waste & 768 & 120 & 26 & 91 & 178 & 585 & 3,028 & 20.2 & 3.29 & 319 & 419 & 263 & 130 & 3,994 \\
\hline Spranghers & Restaurant waste & 738 & 157 & 139 & 45 & 41 & 618 & 4,451 & 19 & 5.87 & 328 & 431 & 386 & 27 & 5,548 \\
\hline \multirow[t]{3}{*}{ et al., 2017} & Fruit and vegetable waste & 873 & 86 & 21 & 108 & 331 & 449 & 2,239 & 15.5 & 5.75 & 304 & 399 & 371 & 96 & 4,805 \\
\hline & Digestate & 757 & 246 & 62 & 299 & 381 & 7 & 785 & 15 & 3.5 & 321 & 422 & 218 & 197 & 3,335 \\
\hline & Chicken feed & 742 & 175 & 53 & 115 & 175 & 425 & 3,030 & 12.3 & 8.51 & 314 & 412 & 336 & 100 & 4,653 \\
\hline Mean & & 788 & 143 & 62 & 104 & 282 & 400 & 2,720 & 17 & 4 & 311 & 408 & 325 & 105 & 4,527 \\
\hline
\end{tabular}

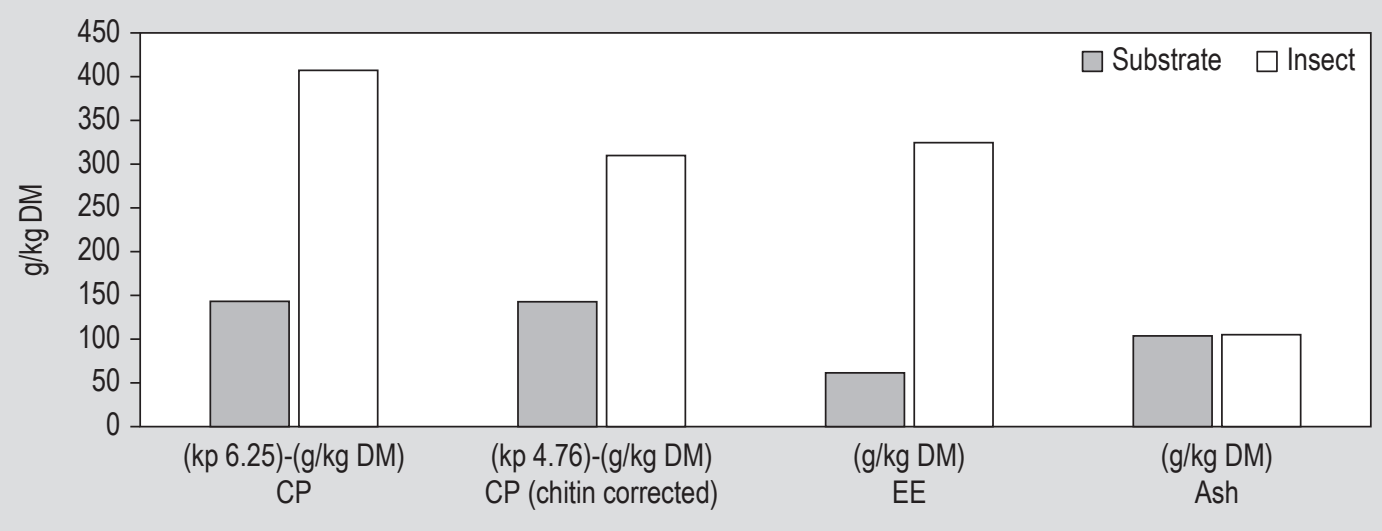

Figure 4. Nutrient content in four different rearing substrates and resulting black soldier fly larval biomass (expressed on DM basis; data from Meneguz et al., 2018; Spranghers et al., 2017). CP = crude protein; DM = dry matter; EE = ether extract.

contrast a large variability was observed in larval material $(287 \pm 151 \mathrm{~g} / \mathrm{kg}$ DM). These figures, however, have to be considered with caution since are based on a limited dataset and can be different in other insect species (Dreassi et al., 2017). Very recently Oonincx and Finke (2021) provided a very exhaustive overview of the nutrients content of insect and how selected nutrients can be manipulated starting from the raring substrate.

The large variability in fat content in larvae can be explained by the ability of BSF larvae to synthesise fatty acids on the basis on different nutrients. In fact, insects can convert carbohydrates into lipids. In the presence of abundant non-fibre carbohydrates in the rearing substrate, BSF larvae mainly synthesise lauric acid (over $50 \%$ of total fatty acids)
(Arrese and Soulages 2010; Meneguz et al., 2018; Oonincx et al., 2015; Spranghers et al., 2017), however in some cases this capacity was also observed with high fibre substrates (Liland et al., 2017; Meneguz et al., 2018). Incidentally, when fat quality (fatty acid profile) is considered, the situation is extremely variable (Pinotti et al., 2019; Schiavone et al., 2017). Moreover, insect fat content is also important in defining technological quality of the resulting insect meals as reported elsewhere (Gasco et al., 2020; Ottoboni et al., 2018; Pinotti et al., 2019)

The average ash content reported in these studies was $51 \pm 50 \mathrm{~g} / \mathrm{kg}$ DM in rearing substrates and $105 \pm 50 \mathrm{~g} / \mathrm{kg}$ DM in larval biomass. It thus seems that BSF larvae tend to accumulate minerals contained in the substrate. In fact, the 
average ash content in larval biomass was twice that in the rearing substrate. Other studies, (Arango Gutiérrez et al., 2004; Newton et al., 1977, 2005), have demonstrated that the ash content of BSF larvae was extremely variable depending on the type of substrate they were grown on. However, considering the mineral composition, Spranghers et al. (2017) found no correlation between any of the elements in the larval biomass and relative substrate. Although ash has no nutritional value, its content needs to be monitored, since ash generally reduces the digestibility of feed and nutrients, therefore limiting the biomass potential.

The interplay between mineral/ash/metal content in substrates and insect bioaccumulation is important for two reasons: (1) insects can accumulate minerals; (2) bioaccumulation can occur for both desirable and undesirable minerals/metals. In this respect some studies (Marone 2016; Purschke et al., 2017) have already indicated that insects - both wild harvested and farm raised - are potentially vulnerable to the accumulation of chemical contaminants, such as metals, ingested via contaminated feed or water.

Considering two (out of seven) of the main farmed insects authorised within the EU as fish feed ingredients, it seems that not only the mineral/metal substrate concentration is important in terms of their accumulation in the insect biomass but also the exposure time. In the case of Tenebrio molitor, Vijver et al. (2003) observed that $\mathrm{Pb}$ and $\mathrm{Cd}$ concentrations of mealworm larvae, reared on spiked soils linearly increase with exposure time. With regard to BSF, in larvae reared on experimentally spiked substrate (Cd, $\mathrm{Pb}$ and $\mathrm{Zn}$ ), Diener et al. (2015) observed an initial accumulation of $\mathrm{Cd}$ in larvae followed by a decrease in adults ascribed to defecation prior to pupation. However no accumulation was observed in the case of $\mathrm{Pb}$ and $\mathrm{Zn}$. In the same species, Purschke et al., (2017), reported a significant bioaccumulation of $\mathrm{Cd}$ and $\mathrm{Pb}$ in BSF larvae, exposed to experimentally contaminated substrates. Of note the bioaccumulation factors were however different: higher than 9 for cadmium, and over 2 for lead. These results indicate that as with all livestock feed insect substrates need to be checked for contaminants in order to ensure feed and food safety standards throughout the value chain.

The fibre (expressed as a NDF, hemicellulose, cellulose, and lignin) substrate content can vary considerably. In fact, the findings of two recent studies, namely Spranghers et al. (2017) and Meneguz et al. (2018), are extremely revealing. They reveal that an insect biomass containing two to four times the substrate's energy content can be obtained from poor energy substrates such as wine/beer fibrous byproducts. Specifically, when BSFs are used to bio-enhance a low energy substrate (i.e. digestate), the energy content of the rearing substrate is increased by over four times in the deriving larvae. By contrast, in the case of energy dense substrates (i.e. restaurant waste), the energy content is only increased by $25 \%$ in the larval biomass, which increases in any case (Figure 1).

These figures highlight that BSF larvae are able to efficiently bio-convert waste and by-products that are high in fibre content (38-55\% NDF), accumulating an appreciable amount of lipids and proteins, without any detrimental effect on their growth performance. This is in confirmed in Meneguz et al. (2018), who reported a very good performance of BSF larvae reared on a high fibre substrate (NDF: 447 g/kg DM; ADF: 225 g/kg DM).

Figure 5 reports the energy content in rearing substrates and BSF larval biomass. Although the formulas used to calculate the energy content were designed for pigs, these figures give a further indication of the potential of insects to upgrade waste material and organic streams. Considering the energy content in substrates, values ranged between $700 \mathrm{kcal} / \mathrm{kg}$ DM in digestate and 4,500 kcal/ $\mathrm{kg}$ DM in restaurant waste. On the other hand, the energy content varied from 3,000 $\mathrm{kcal} / \mathrm{kg} \mathrm{DM}$ and $5,500 \mathrm{kcal} / \mathrm{kg}$ DM in the larval biomass.

These figures highlight that larvae efficiently bio-convert waste and by-products with a high fibre content (38-55\% NDF) without any detrimental effect on their growth performance. In addition, their ability to convert 'fibre in fat' enhances their potential and efficiency: it would seem that insects are able to return over twice the amount of energy than that introduced into the rearing system. The ability of BSF larvae to bio convert fibre rich substrate may be partially explained by the presence, in the digestive tract of the insect, of intestinal bacteria able to degrade cellulose (Kim et al., 2014b).

\section{Time needed to reach the harvesting stage}

Although several environmental factors such as temperature, light, and humidity are known to affect growth and development of insect (Oonincx and Finke, 2021), a further factor that needs to be considered in defining the substrate is the 'time' needed to reach the harvesting stage. As reported in Figure 6, different substrates can accelerate or delay the development time needed to rear insects.

Balanced diets, as in the case of chicken feed, would seem able to accelerate the growing phase of BSF larvae, thus reducing the time needed to reach the harvesting state by up to $50 \%$. Most other substrates are able to guarantee the harvesting within four weeks. The only exceptions are industrial by-products as in the case of the brewery byproduct (BRE) substrate obtained during beer production (Meneguz et al., 2018). The growth dynamics and waste reduction efficiency parameters of BSF larvae grown on BRE were found to be excellent. The BRE larvae in fact, showed a very good performance despite the high structural 


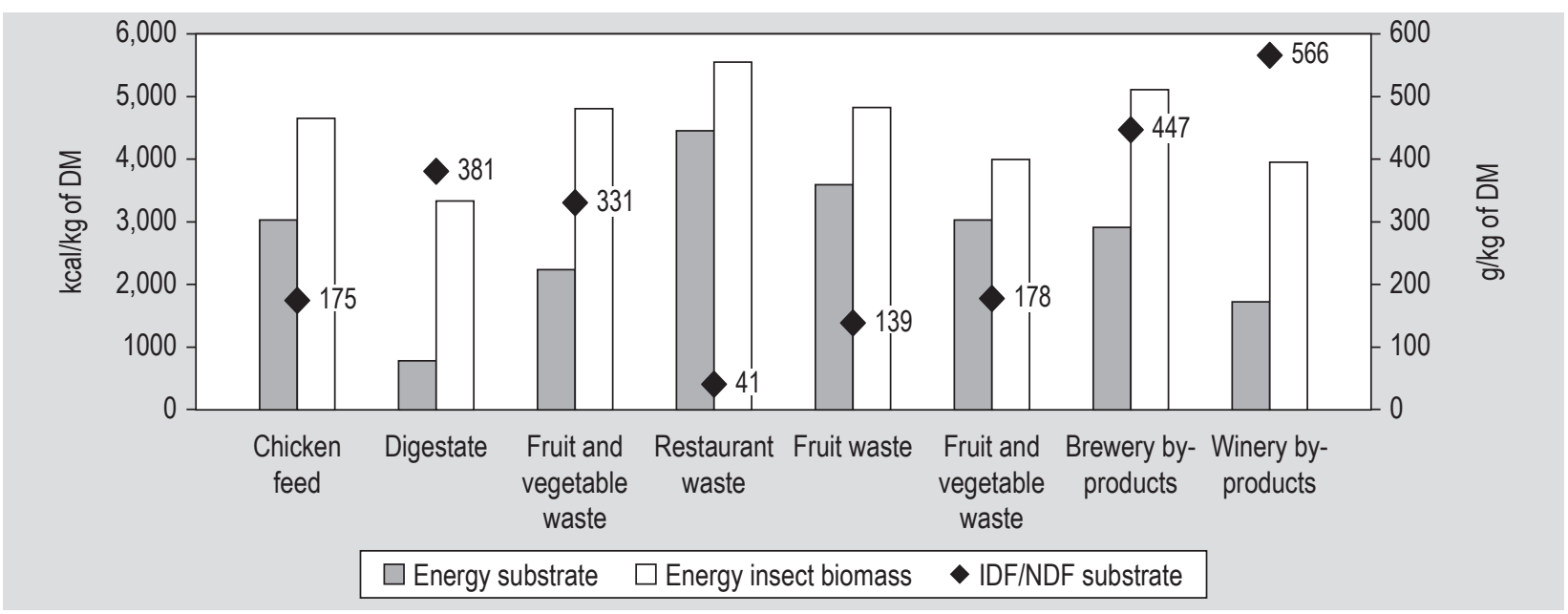

Figure 5. Energy content in substrates and insect biomass, insoluble dietary fibre (IDF) or neutral detergent fibre (NDF) content (४) in the substrate (g/kg DM) in Spranghers et al. (2017) and Meneguz et al. (2018).

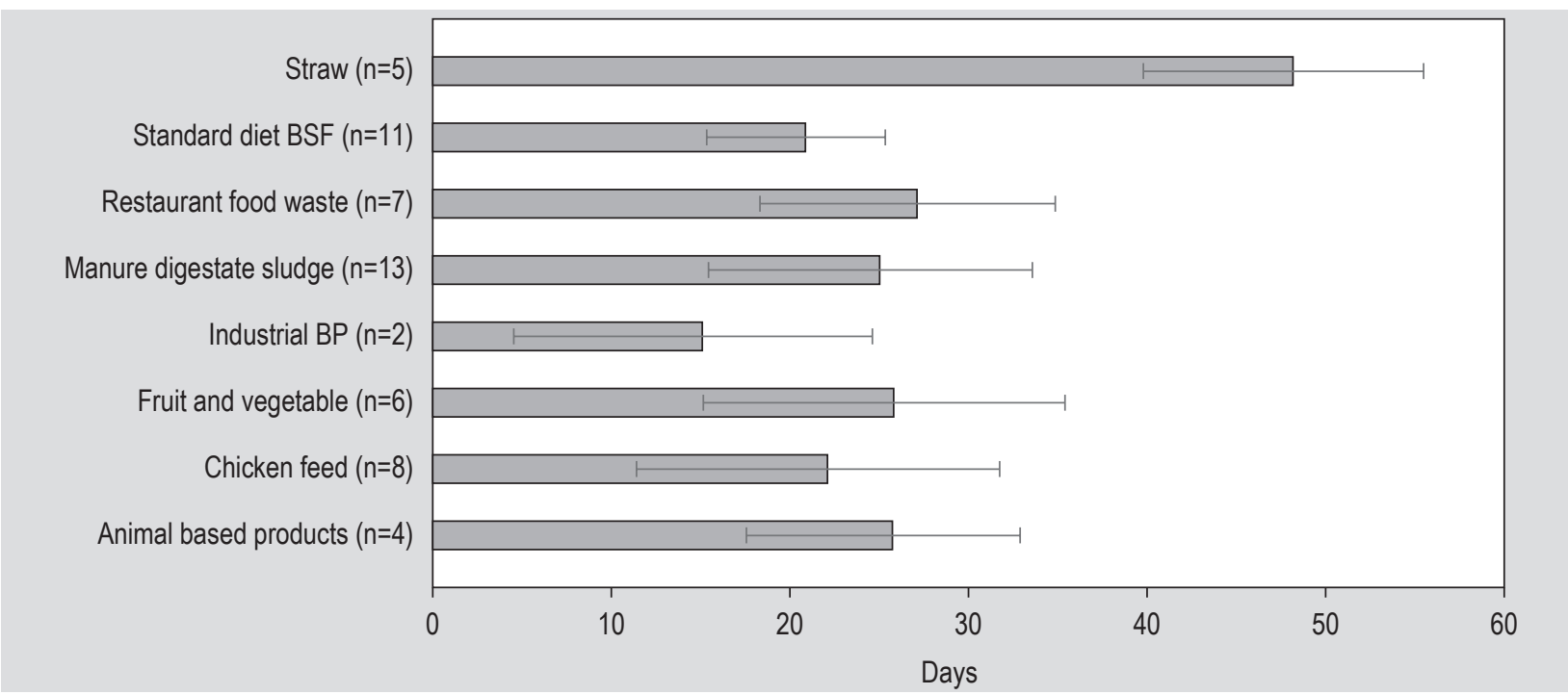

Figure 6. Graphical representation of days (mean, standard deviation, and number of replicates ' $n$ ') needed by black soldier fly (BSF) larvae for reaching the prepupal stage mean and standard deviation according to relative rearing substrate class, namely, straw, standard diet BSF, restaurant food waste, manure digestate sludge, industrial byproducts (BP), fruit and vegetable, chicken feed, animal based products. Data elaborated from studies reported in Table S1.

carbohydrate content of the relative rearing substrate (NDF: approximately $45 \%$ on a DM basis; ADF: $23 \%$ ), reaching the harvesting phase in less than 2 weeks (Meneguz et al., 2018). These results however clearly demonstrate that BSF larvae are able to efficiently bio convert waste and byproducts characterised by a high fibre content, thanks to the presence, in their digestive tract of fibrolytic bacteria (Kim et al., 2014b). By contrast, straw slowed the growth of the larvae, which need almost 50 days before they can be harvested. The role of lignin in these results is still unclear. The same scenario was also confirmed when the insect biomass produced was plotted against development time (Figure 7).
Another key nutrient in defining the time needed to reach the harvesting stage seems to be the protein content in growing substrate. Oonincx et al. (2015) observed that in the BSF the growing performances in term of feed conversion rate and efficiency of conversion of ingested foods were similar over dietary treatments, although they tended to use the low protein diets (13-14\% CP) less efficiently than the other diets. By contrast the same trial evidenced that BSF larvae developed faster when a high protein and energy dense diet was administered (Oonincx et al., 2015). Similarly, Barragán-Fonseca et al. (2018) have observed that development time were largely affected by selected nutrient concentration. Specifically, development time increased with lower protein content. These two studies used both 


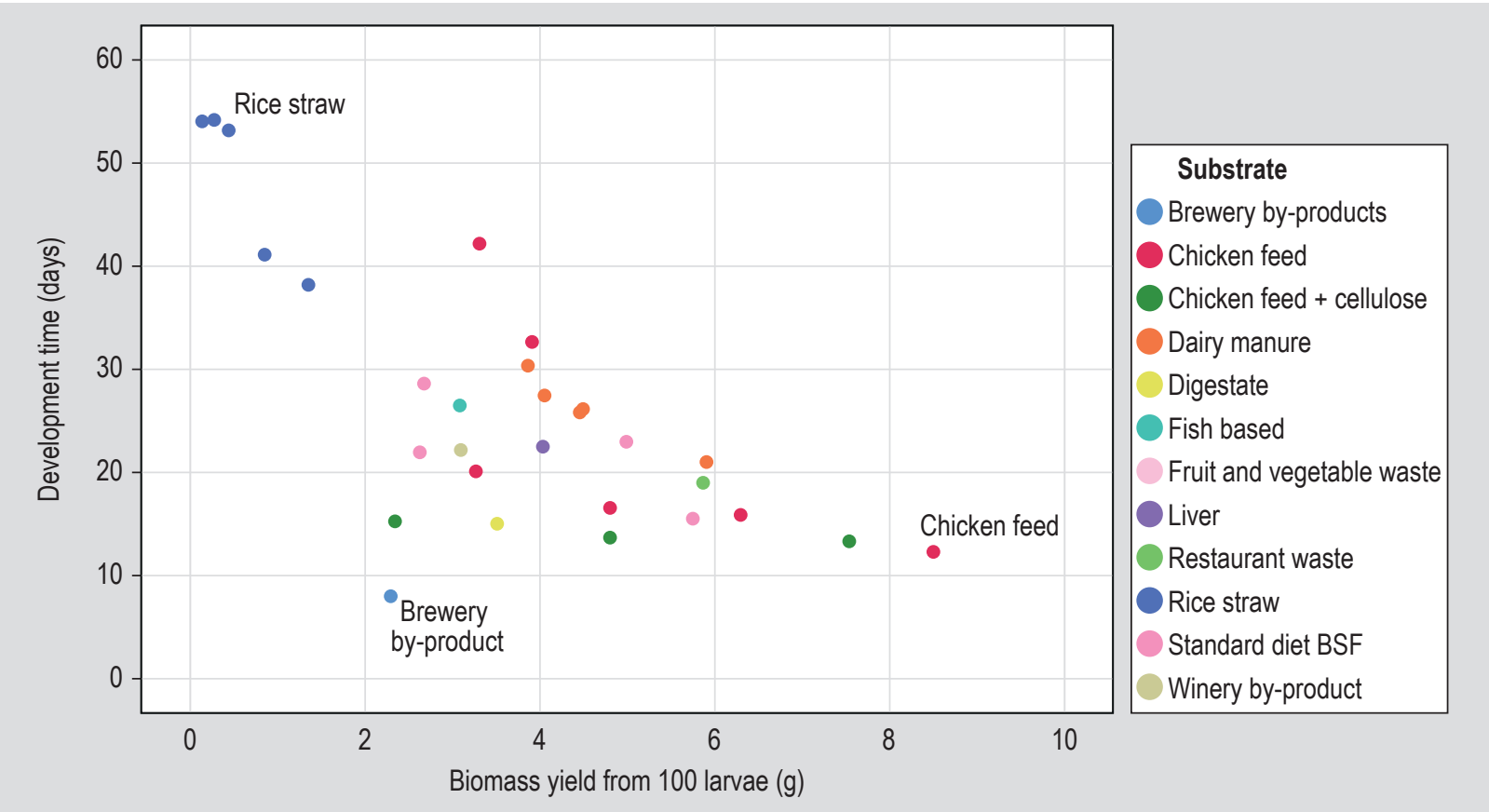

Figure 7. Biomass yield from 100 larvae (g) plotted against development time (days). Data elaborated from studies reported in Table S1.

vegetable based diet. However, the effect of substrate protein concentration on development time was similar when animal sources were included (Nguyen et al., 2013). Some of these issue have been also addressed by Oonincx and Finke in a recent review (2020), in which the authors suggested that variation in amino acid patterns between life stages (i.e. age) of a species partially depends on whether that species undergoes complete metamorphosis - as in the case of BSF-or incomplete metamorphosis.

\section{Conclusions}

The aim of the present work was to review the main rearing substrates reported in the literature for farmed insects. The focus was on offering a broad analysis of different substrates for all insects, and especially those used for BSF larvae.

Although most of the data reviewed highlight the huge potential of insects to upgrade 'low input' substrates with a high value biomass, several aspects still need clarification. One of the main issues in insect livestock is the lack of standardisation, not only in practice but also during the research and development process. For instance, in one day, BSF larvae can reduce 30 metric tons of food waste to ca. 10 metric tons (waste reduction 66\%), while producing $930 \mathrm{~kg}$ of dry biomass (Chia et al., 2019; Salomone et al., 2017). Based on the figure efficiency can be very low, even though in the balance it must be considered that insect are reared on organic waste, which would otherwise end up in dumpsites, causing environmental pollution (Chia et al., 2019). These figures clearly indicate that standard performance indicators are needed to prevent any misunderstanding in the evaluation of the microlivestock system.

An insect Substrate Conversion Rate needs to be devised, expressed in dry matter in order to avoid confusion, along with specific normalisation units. For instance, when the insect production/yield is reported, its normalisation is essential, for example, the grams of larval biomass yield (DM) on the basis of 100 young larvae. These can be obtained not only through an extensive assessment of insect livestock systems and conditions, but also by defining the common standard reference indicators that are generally recognised.

Considering the feeding rate, the optimal performance in terms of grams of larval biomass yield (DM) on the basis of 100 young larvae and time needed to reach the harvesting stage, is obtained when feeding $200 \mathrm{mg} /$ day/larvae (Diener et al., 2009). This quantity however has to be consider as indicative since as reported elsewhere (Oonincx and Finke, 2021) above the feeding rate other many possible factors can affect insect growth. Among those larvae density, for instance, has been reported as one of the main important (Barragán-Fonseca et al., 2018).

In terms of nutritional value, this review shows how insects are able to upgrade and convert an unbalanced carbohydrates-based (70-90\%) substrate, into a more balanced biomass that combines proteins, lipids, and carbohydrates (ratio protein, lipids, carbohydrates 34:33:33 $\pm 5.2: 9.6: 8.9$ ) depending on the diet. 
However care needs to be taken regarding undesirable compounds in rearing substrate such as ANFs and contaminants. In the case of ANFs, marine materials may contain alginate and fucoidan, for which several side effects have been reported such as a reduced insect growth rate. In the case of contaminant like heavy metals, it seems that accumulation and excretion patterns show similarities at different levels such as order (i.e. also species) and life stages. Variation in dietary intake levels will to some extent affect insect concentrations (Oonincx and Finke, 2021). Furthermore, evidence indicates that that not only the mineral/metal substrate concentration is important for their accumulation in the insect biomass, but also the exposure time. For example for heavy metals, the bio-accumulation factor is higher than 9 for cadmium, and over 2 for lead. This thus indicates that insect substrates as with all livestock feed, require monitoring for contaminants in order to ensure feed and food safety standards throughout the value chain. A further point that has to be consider is 'what insect prefer'. In this direction a recent study (Morales-Ramos et al., 2020) on self-selection of food ingredients and agricultural byproducts by cricket, evidenced something new. Specifically, among several ingredients tested, some materials have shown a greatest selective/preference consumption by these species; rice bran (whole and defatted), corn dry distillers grain, buckwheat, and dry cabbage, were the most preferred by the crickets under experimental conditions. Accordingly, these five ingredients have been proposed as key ingredients for insect diet development in the future.

An additional aspect that has been not fully addressed in the literature whether the substrate should be changed during the various rearing phases. Even investigate in different scenario (the aim was to study how the substrate exposure can shape insect mycobiota; Varotto Bocazzi et al., 2017), the findings showed that it is possible to 'design' the insect composition by combining the substrates and time of exposure. In summary, the substrate on which insects are maintained significantly contributes to shaping the nutrient composition of the resulting insect material, although the effect of time needs further investigation.

\section{Acknowledgements}

The present work has been done in the frame of the following project: Sustainable feed design applying circular economy principles: the case former food in pig nutrition (SusFEED-Rif. Pratica: 2018-0887); funded by the Fondazione Cariplo within the framework of the following call: Economia circolare: ricerca per un futuro sostenibile.

\section{Conflict of interest}

The authors declare no conflict of interest.

\section{Supplementary material}

Supplementary material can be found online at https://doi. org/10.3920/JIFF2020.0110.

Table S1. Studies on the suitability of different substrates for black soldier fly larvae.

\section{References}

Arango Gutiérrez, G.P., Vergara Ruiz, R.A. and Mejía Vélez, H., 2004. Compositional, microbiological and protein digestibility analysis of the larva meal of Hermetia illuscens L.(Diptera: Stratiomyiidae) at Angelópolis-Antioquia, Colombia. Revista Facultad Nacional de Agronomía Medellín 57: 2491-2500.

Arrese, E.L. and Soulages, J.L., 2010. Insect fat body: energy, metabolism, and regulation. Annual Review of Entomology 55: 207-225. https://doi.org/10.1146/annurev-ento-112408-085356

Barragan-Fonseca, K.B., Dicke, M. and Van Loon, J.J., 2018. Influence of larval density and dietary nutrient concentration on performance, body protein, and fat contents of black soldier fly larvae (Hermetia illucens). Entomologia Experimentalis et Applicata 166: 761-770. https://doi.org/10.1111/eea.12716

Biancarosa, I., Liland, N.S., Biemans, D., Araujo, P., Bruckner, C.G., Waagbø, R., Torstensen, B.E., Locka, E.J. and Amlund, H., 2017. Uptake of heavy metals and arsenic in black soldier fly (Hermetia illucens) larvae grown on seaweed-enriched media. Journal of the Science of Food and Agriculture 98: 2176-2183. https://doi. org/10.1002/jsfa.8702

Bruno, D., Bonelli, M., De Filippis, F., Di Lelio, I., Tettamanti, G., Casartelli, M., Ercolini, D. and Caccia, S., 2019. The intestinal microbiota of Hermetia illucens larvae is affected by diet and shows a diverse composition in the different midgut regions. Applied and Environmental Microbiology 85: e01864-18. https://doi.org/10.1128/ AEM.01864-18

Chia, S.Y., Tanga, C.M., Van Loon, J.J. and Dicke, M., 2019. Insects for sustainable animal feed: inclusive business models involving smallholder farmers. Current Opinion in Environmental Sustainability 41: 23-30. https://doi.org/10.1016/j.cosust.2019.09.003 Dicke, M. 2018. Insects as feed and the Sustainable Development Goals. Journal of Insects as Food and Feed 4: 147-156. https://doi. org/10.3920/JIFF2018.0003

Diener, S., Zurbrügg, C. and Tockner, K., 2015. Bioaccumulation of heavy metals in the black soldier fly, Hermetia illucens and effects on its life cycle. Journal of Insects as Food and Feed 1: 261-270. https://doi.org/10.3920/JIFF2015.0030

Diener, S., Zurbrügg, C. and Tockner, K., 2009. Conversion of organic material by black soldier fly larvae: establishing optimal feeding rates. Waste Management and Research 27: 603-610. https://doi. org/10.1177/0734242X09103838

Dreassi, E., Cito, A., Zanfini, A., Materozzi, L., Botta, M. and Francardi, V., 2017. Dietary fatty acids influence the growth and fatty acid composition of the yellow mealworm Tenebrio molitor (Coleoptera: Tenebrionidae). Lipids 52: 285-294. https://doi.org/10.1007/s11745016-4220-3 
Dzepe, D., Nana, P., Fotso, A., Tchuinkam, T. and Djouaka, R., 2020. Influence of larval density, substrate moisture content and feedstock ratio on life history traits of black soldier fly larvae. Journal of Insects as Food and Feed 6: 133-140. https://doi.org/10.3920/JIFF2019.0034 European Commission (EC), 2017. Commission Regulation (EU) No. 2017/893 of 24 May 2017 amending Annexes I and IV to Regulation (EC) No. 999/2001 of the European Parliament and of the Council and Annexes X, XIV and XV to Commission Regulation (EU) No. $142 / 2011$ as regards the provisions on processed animal protein. Official Journal L 138/92: 1-25.

European Commission (EC), 2001. Commission Regulation (EU) No. 999/2001 of the European Parliament and of the Council of 22 May 2001 laying down rules for the prevention, control and eradication of certain transmissible spongiform encephalopathies. Official Journal of the European Union L 147: 1-40.

European Commission (EC), 2009a. Commission Regulation (EU) No. 767/2009 of the European Parliament and of the council of 13 July 2009 on the placing on the market and use of feed, amending European Parliament and Council Regulation (EC) No 1831/2003 and repealing Council Directive 79/373/EEC, Commission Directive 80/511/EEC. Official Journal of the European Union L 229(1): 1-28.

European Commission (EC), 2009b. Commission Regulation (EU) No. 1069/2009 of the European Parliament and of the Council of 21 October 2009 laying down health rules as regards animal byproducts and derived products not intended for human consumption and repealing Regulation (EC) No. 1774/2002 (Animal by-products Regulation). Official Journal of the European Union L 300(1): 1-33.

European Commission (EC), 2013.Commission Regulation (EU) No. 68/2013 of the European Parliament and of the Council of 16 January 2013 on the Catalogue of feed materials. Official Journal of the European Union L29: 1-64.

European Food Safety Authority (EFSA) Scientific Committee, 2015. Risk profile related to production and consumption of insects as food and feed. EFSA Journal 13: 4257. https://doi.org/10.2903/j.efsa.2015.4257

Food and Agriculture Organisation (FAO), 2013. Edible insects: future prospects for food and feed security. FAO, Rome, Italy. Available at: http://www.fao.org/3/i3253e/i3253e.pdf

Gasco, L. Acuti, G., Bani, P., Dalle Zotte, A., Danieli, P.P., De Angelis, A., Fortina, R., Marino, R., Parisi, G., Piccolo, G., Pinotti, L., Prandini, A., Schiavone, A., Terova, G., Tulli, F. and Roncarati, A., 2020 Insect and fish by-products as sustainable alternatives to conventional animal proteins in animal nutrition. Italian Journal of Animal Science 19(1): 360-372. https://doi.org/10.1080/1828051X.2020.1743209

Giromini, C., Ottoboni, M., Tretola, M., Marchis, D., Gottardo, D., Caprarulo, V., Baldi, A. and Pinotti, L., 2017. Nutritional evaluation of former food products (ex-food) intended for pig nutrition. Food Additives \& Contaminants: Part A 34: 1436-1445. https://doi.org/ 10.1080/1944.0049.2017.1306884

Gummert, M., Van Hung, N., Chivenge, P. and Douthwaite, B., 2020. Sustainable rice straw management. Springer International Publishing, Cham, Switzerland, 192 pp. https://doi.org/10.1007/9783-030-32373-8

Hall, A.C., Fairclough, A.C., Mahadevan, K. and Paxman, J.R., 2012. Ascophyllum nodosum enriched bread reduces subsequent energy intake with no effect on post-prandial glucose and cholesterol in healthy, overweight males. A pilot study. Appetite 58: 379-386. https://doi.org/10.1016/j.appet.2011.11.002
Hamm, J., 2017. The economics of feed drying: processing. AFMA Matrix 26: 12-13.

Heuzé, V. and Tran, G., 2015. Rice straw. Feedipedia, a programme by INRA, CIRAD, AFZ and FAO. Available at: https://www.feedipedia. org/node/557.

Janssen, R.H., Vincken, J.P., Van den Broek, L.A., Fogliano, V. and Lakemond, C.M., 2017. Nitrogen-to-protein conversion factors for three edible insects: Tenebrio molitor, Alphitobius diaperinus, and Hermetia illucens. Journal of Agricultural and Food Chemistry 65: 2275-2278. https://doi.org/10.1021/acs.jafc.7b00471

Kim, E., Park, J., Lee, S. and Kim, Y., 2014b. Identification and physiological characters of intestinal bacteria of the black soldier fly, Hermetia illucens. Korean Journal of Applied Entomology 53: 15-26.

Kim, K.T., Rioux, L.E. and Turgeon, S.L., 2014a. Alpha-amylase and alpha-glucosidase inhibition is differentially modulated by fucoidan obtained from Fucus vesiculosus and Ascophyllum nodosum. Phytochemistry 98: 27-33. https://doi.org/10.1016/j. foodchem.2013.04.123

Lalander, C., Ermolaev, E., Wiklicky, V. and Vinnerås, B., 2020. Process efficiency and ventilation requirement in black soldier fly larvae composting of substrates with high water content. Science of The Total Environment 729: 138968. https://doi.org/10.1016/j. scitotenv.2020.138968

Liland, N.S., Biancarosa, I., Araujo, P., Biemans, D., Bruckner, C.G., Waagbø, R., Torstensen, B.E. and Lock, E.J., 2017. Modulation of nutrient composition of black soldier fly (Hermetia illucens) larvae by feeding seaweed-enriched media. PLoS ONE 12: e0183188. https://doi.org/10.1371/journal.pone.0183188

Liu, Z., Minor, M., Morel, P.C. and Najar-Rodriguez, A.J., 2018. Bioconversion of three organic wastes by black soldier fly (Diptera: Stratiomyidae) larvae. Environmental Entomology 47: 1609-1617. https://doi.org/10.1093/ee/nvy141

Luciano, A., Tretola, M., Ottoboni, M., Baldi, A., Cattaneo, D. and Pinotti, L., 2020. Potentials and challenges of former food products (food leftover) as alternative feed ingredients. Animals 10: 125. https://doi.org/10.3390/ani10010125

Manurung, R., Supriatna, A., Esyanthi, R.R. and Putra, R.E., 2016. Bioconversion of rice straw waste by black soldier fly larvae (Hermetia illucens L.): optimal feed rate for biomass production. Journal of Entomology and Zoology Studies 4: 1036-1041.

Marone, P.A., 2016. Food safety and regulatory concerns. In: Dossey, A.T., Morales-Ramos, J.A. and Guadalupe Rojas, M. (eds.) Insects as sustainable food ingredients. Academic Press, Cambridge, MA, USA, pp. 203-221.

McDonald, P., Edwards, R.A., Greenhalgh, J.F.D., Morgan, C.A., Sinclair, L.A. and Wilkinson, R.G., 2012. Animal nutrition, $7^{\text {th }}$ edition. Pearson Education Ltd., Essex, UK, 762 pp.

Meneguz, M., Schiavone, A., Gai, F., Dama, A., Lussiana, C., Renna, M. and Gasco, L., 2018. Effect of rearing substrate on growth performance, waste reduction efficiency and chemical composition of black soldier fly (Hermetia illucens) larvae. Journal of the Science of Food and Agriculture 98: 5776-5784. https://doi.org/10.1002/jsfa.9127 Morales-Ramos, J.A., Rojas, M.G., Dossey, A.T., Berhow, M., 2020. Self-selection of food ingredients and agricultural by-products by the house cricket, Acheta domesticus (Orthoptera: Gryllidae): a holistic approach to develop optimized diets. PLoS ONE 15(1): e0227400. https://doi.org/10.1371/journal.pone.0227400 
Münke-Svendsen, C., Halloran, A., Oloo, J., Henlay, J.O., Nyakeri, M., Manyara, E. and Roos, N., 2017. Technical Brief \#2: insect production systems for food and feed in Kenya. GREEiNSECT. https://doi.org/10.13140/RG.2.2.24053.99040

Newton, G.L., Booram, C.V., Barker, R.W. and Hale, O.M., 1977. Dried Hermetia illucens larvae meal as a supplement for swine. Journal of Animal Science 44: 395-400. https://doi.org/10.2527/ jas1977.443395x

Newton, L., Sheppard, C., Watson, D.W., Burtle, G. and Dove, R. 2005. Using the black soldier fly, Hermetia illucens, as a value-added tool for the management of swine manure. Animal and Poultry Waste Management Center, North Carolina State University, Raleigh, NC, USA.

Nguyen, T.T., Tomberlin, J.K. and Vanlaerhoven, S., 2013. Influence of resources on Hermetia illucens (Diptera: Stratiomyidae) larval development. Journal of Medical Entomology 50: 898-906. https:// doi.org/10.1603/me12260

Oonincx, D.G.A.B. and Finke, M.D., 2021. Nutritional value of insects and ways to manipulate their composition. Journal of Insects as Food and Feed 7: 639-659. https://doi.org/10.3920/JIFF2020.0050

Oonincx, D.G.A.B., Van Broekhoven, S., Van Huis, A. and Van Loon, J.J., 2015. Feed conversion, survival and development, and composition of four insect species on diets composed of food byproducts. PLoS ONE 10: e0144601. https://doi.org/10.1371/journal. pone. 0144601

Ortiz, J.C., Ruiz, A.T., Morales-Ramos, J.A., Thomas, M., Rojas, M.G., Tomberlin, J.K., Yi, L., Han, R., Giroud, L. and Jullien, R.L., 2016. Insect mass production technologies. In: Dossey, A.T., MoralesRamos, J.A. and Guadalupe Rojas, M. (eds.). Insects as sustainable food ingredients: production, processing and food applications. Academic Press, London, UK, pp. 153-201.

Ottoboni, M., Spranghers, T., Pinotti, L., Baldi, A., De Jaeghere, W. and Eeckhout, M., 2018. Inclusion of Hermetia illucens larvae or prepupae in an experimental extruded feed: process optimisation and impact on in vitro digestibility. Italian Journal of Animal Science 17: 418-427. https://doi.org/10.1080/1828051X.2017.1372698

Ottoboni, M., Tretola, M., Cheli, F., Marchis, D., Veys, P., Baeten, V. and Pinotti, L., 2017. Light microscopy with differential staining techniques for the characterisation and discrimination of insects versus marine arthropods processed animal proteins. Food Additives and Contaminants - Part A Chemistry, Analysis, Control, Exposure and Risk Assessment 34(8): 1377-1383. https://doi.org/10.1080/1 9440049.2016.12784.64

Ottoboni, M., Tretola, M., Luciano, A., Giuberti, G., Gallo, A. and Pinotti, L., 2019. Carbohydrate digestion and predicted glycemic index of bakery/confectionary ex-food intended for pig nutrition. Italian Journal of Animal Science 18: 838-849. https://doi.org/10. 1080/1828051X.2019.1596758

Pinotti, L., Giromini, C., Ottoboni, M., Tretola, M. and Marchis, D., 2019. Insects and former foodstuffs for upgrading food waste biomasses/streams to feed ingredients for farm animals. Animal 13: 1365-1375. https://doi.org/10.1017/S1751731118003622
Pinotti, L., Luciano, A., Ottoboni, M., Manoni, M., Ferrari, L., Marchis, D. and Tretola, M., 2021. Recycling food leftovers in feed as opportunity to increase the sustainability of livestock production. Journal of Cleaner Production 294: 126290. https://doi.org/10.1016/j. jclepro.2021.126290

Pinotti, L., Manoni, M., Fumagalli, F., Rovere, N., Luciano, A., Ottoboni, M., Ferrari, L., Cheli, F. and Djuragic, O., 2020. Reduce, reuse, recycle for food waste: a second life for fresh-cut leafy salad crops in animal diets. Animals 10(6): 1082. https://doi.org/10.3390/ani10061082

Purschke, B., Scheibelberger, R., Axmann, S., Adler, A. and Jäger, H., 2017. Impact of substrate contamination with mycotoxins, heavy metals and pesticides on the growth performance and composition of black soldier fly larvae (Hermetia illucens) for use in the feed and food value chain. Food Additives \& Contaminants: Part A 34: 1410-1420. https://doi.org/10.1080/19440049.2017.1299946.

Salomone, R., Saija, G., Mondello, G., Giannetto, A., Fasulo, S., Savastano, D., 2017. Environmental impact of food waste bioconversion by insects: application of life cycle assessment to process using Hermetia illucens. Journal of Cleaner Production 140: 890-905. https://doi.org/10.1016/j.jclepro.2016.06.154

Schiavone, A., Cullere, M., De Marco, M., Meneguz, M., Biasato, I., Bergagna, S., Dezzutto, D., Gai, F., Dabbou, S., Gasco, L. and Dalle Zotte, A., 2017. Partial or total replacement of soybean oil by black soldier fly larvae (Hermetia illucens L.) fat in broiler diets: effect on growth performances, feed-choice, blood traits, carcass characteristics and meat quality. Italian Journal of Animal Science 16(1): 93-100. https://doi.org/10.1080/1828051X.2016.1249968

Spranghers, T., Ottoboni, M., Klootwijk, C., Ovyn, A., Deboosere, S., De Meulenaer, B., Michiels, J., Eeckhout, M., De Clercq P. and De Smet, S., 2017. Nutritional composition of black soldier fly (Hermetia illucens) prepupae reared on different organic waste substrates. Journal of the Science of Food and Agriculture 97: 25942600. https://doi.org/10.1002/jsfa.8081

Tretola, M., Ottoboni, M., Luciano, A., Rossi, L., Baldi, A. and Pinotti, L., 2019. Former food products have no detrimental effects on diet digestibility, growth performance and selected plasma variables in post-weaning piglets. Italian Journal of Animal Science 18: 987-996. https://doi.org/10.1080/1828051X.2019.1607784

Varotto Boccazzi, I., Ottoboni, M., Martin, E., Comandatore, F., Vallone, L., Spranghers, T., Eeckhout, M., Mereghetti, V., Pinotti, L. and Epis, S., 2017. A survey of the mycobiota associated with larvae of the black soldier fly (Hermetia illucens) reared for feed production. PLoS ONE 12(8): e0182533. https://doi.org/10.1371/ journal.pone.0182533

Veldkamp, T. and Eilenberg, J., 2018. Insects in European feed and food chains. Journal of Insects as Food and Feed 4: 143-145. https:// doi.org/10.3920/JIFF2018.x006

Vijver, M., Jager, T., Posthuma, L. and Peijnenburg, W., 2003. Metal uptake from soils and soil-sediment mixtures by larvae of Tenebrio molitor (L.)(Coleoptera). Ecotoxicology and Environmental Safety 54: 277-289. https://doi.org/10.1016/S0147-6513(02)00027-1 